\title{
Sense expression
}
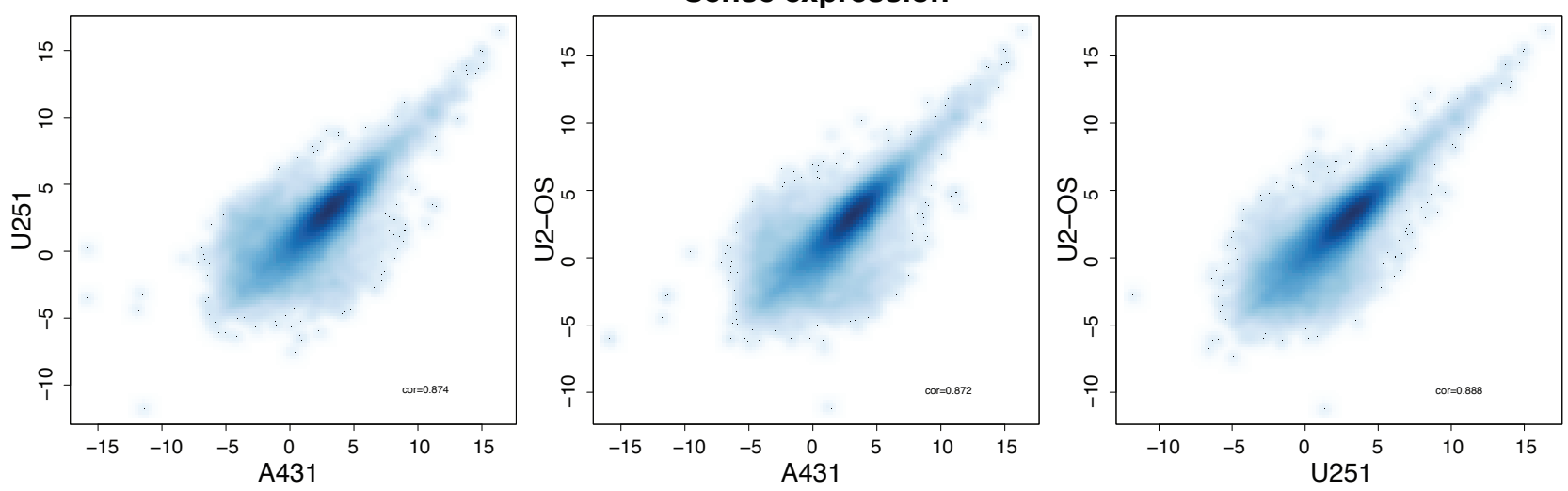